\title{
Breast Cancer Immunotherapy: From Biology to Current Clinical Applications
}

\begin{abstract}
Authors:
*Jorge Henrique Santos Leal,, Heather McArthur²

1. CLION, CAM Group, Salvador, Brazil

2. Cedars-Sinai Medical Center Samuel Oschin Comprehensive Cancer Institute, Los Angeles, California, USA

*Correspondence to jorge.leal@clion.com.br

Disclosure: $\quad$ Dr Leal has received personal fees from Pfizer, Roche/Genentec, Novartis, and AstraZeneca, outside the submitted work. Dr McArthur has received grants from Merck, and Medlmmune/AstraZeneca; nonfinancial support from Merck, BristolMyers Squibb, and MedImmune/AstraZeneca; and personal fees from Merck, Roche/Genentech, Eli Lilly, Peregrine Pharmaceuticals, Taplmmune Inc., Amgen, Puma Biotechnology, Pfizer, Immunomedics, Syndax, Genomic Health, Spectrum Pharmaceuticals Inc., OBI Pharma Inc., Calithera Biosciences, and Celgene, outside the submitted work.
\end{abstract}

Received:

15.11.19

Accepted:

12.02 .20

Keywords:

Breast cancer, cytotoxic T-lymphocyte antigen-4 (CTLA-4), immunotherapy, immune checkpoint inhibitors, programmed cell death-1 (PD1), programmed cell death ligand-1 (PD-L1).

Citation:

EMJ. 2020;5[2]:113-124.

\section{Abstract}

Therapeutic strategies for the treatment of breast cancer have historically been determined by the presence or absence of hormone receptors and HER2 amplification and/or protein expression. For patients with breast cancer that lack these biomarkers, the so-called 'triple-negative' subtype, chemotherapy has been the cornerstone of cure and palliation. However, with the recent successful development of immune checkpoint molecules that target cytotoxic T-lymphocyte antigen-4, programmed cell death-1 (PD-1), and PD-ligand 1 (PD-L1), improved survival has been reported across a range of tumour types including melanoma, lung, and bladder cancer. In metastatic breast cancer, trials of single-agent immune checkpoint inhibitors $(\mathrm{ICl})$ have resulted in limited overall response rates; however, strategies that combine local or systemic therapies with $\mathrm{ICl}$ have improved response rates and, in some cases, improved survival. For example, the addition of an anti-PD-L1 inhibitor, atezolizumab, to nab-paclitaxel chemotherapy for newly diagnosed metastatic triple-negative breast cancer demonstrated an improvement in overall survival in an informal analysis of the PD-L1-positive subset in a recently reported Phase III clinical trial. These results ultimately led to U.S. Food and Drug Administration (FDA) approval for an $\mathrm{ICl}$ for the treatment of breast cancer, with numerous other health authorities following suit. Herein, the authors describe the biology behind $\mathrm{ICl}$, the rationale for $\mathrm{ICl}$ administration in breast cancer, the related clinical trial data reported to date, and promising future strategies. 


\section{INTRODUCTION}

The complexity behind the treatment of breast cancer arises, in part, from the presence of biologically distinct subtypes. Clinically, subtypes are currently defined either by immunohistochemistry for hormone receptor and HER2 status, ${ }^{1,2}$ or by high-throughput diagnostic technology such as gene expression arrays or next-generation sequencing. ${ }^{3}$ From third-generation chemotherapy to monoclonal antibodies and tyrosine kinase inhibitors, the breast cancer treatment armamentarium continues to evolve. ${ }^{4}$ However, innovative strategies are still needed to improve cure rates.

Integrating systemic and local therapy has been shown to be the best strategy to achieve longterm survival for early-stage breast cancer. ${ }^{5}$ In the metastatic breast cancer (MBC) scenario, symptom control and increased survival are the most important objectives during systemic therapy. For patients with oestrogen receptor (ER) positive (+) breast cancer, great advances have been achieved in recent years incorporating targeted therapies such as mTOR inhibitors, cyclin-dependent kinase 4/6 inhibitors, and phosphoinositide 3-kinase inhibitors with conventional hormone therapy. ${ }^{6}$ Treatment of HER2+ MBC dramatically changed with dual HER2 blockade and trastuzumab emtansine treatment.,8 In patients with $B R C A 1 / 2$ germline mutations, treatment with poly (ADP-ribose) polymerase (PARP) inhibitors increases survival, compared with conventional chemotherapy. ${ }^{9}$ Patients lacking ER, HER2, and progesterone receptor expression have the triple-negative breast cancer (TNBC) subtype. Unfortunately, patients with TNBC with no BRCA mutations only have chemotherapy as an available therapy option, and this treatment generally has a poor prognosis. ${ }^{10}$

\section{Tumour-infiltrating lymphocytes (TIL) are} mononuclear immune cells that infiltrate tumour tissue and have been observed in most types of solid tumours, including breast, colon, lung, cervical cancer, and melanoma." For breast cancer, recent studies have reported that TIL may play an important role in determining prognosis and response to therapy. Retrospective analyses of tissue samples from multiple clinical trials have shown a strong relationship between

high levels of TIL by immunohistochemistry and improved outcomes. ${ }^{12}$ The HER2+ and TNBC subtypes appear to have the highest TIL expression ${ }^{13}$ and across these two subtypes there is a correlation between the presence of TIL and increased levels of programmed cell death ligand-1 (PD-L1) expression. ${ }^{14}$ Some hormone receptor+ breast cancers also demonstrate high TIL levels. Thus, strategies that augment innate antitumour immune activity, or induce immune activity in immunologically 'cold' tumours, may be relevant across breast cancer subtypes. In this review, the authors summarise the biologic rationale for immune modulation in breast cancer, describe and discuss breast cancer immunotherapy clinical trial data presented or published to date, and highlight some ongoing clinical trials that are potentially poised to change future oncology practice, with a focus on immune checkpoint inhibitors ( $\mathrm{ICl}$ ).

\section{THE BIOLOGY BEHIND IMMUNOTHERAPY IN BREAST CANCER}

The first evidence implicating the immune system in controlling tumour growth came from Dr William Coley, who administered bacterial fragments (which became known as 'Coley's toxins') to induce tumour shrinkage in the 1890s. ${ }^{15}$ Numerous clinical trials have since tested vaccines developed from inactivated cancer cells with very few clinical responses. ${ }^{16}$ Great progress was made after scientists focussed their research on cancer immunology to map the molecular mechanisms of T-cell antigen recognition, regulation, and function. A crucial step was understanding how the immune system balances an active immune phenotype to prevent autoimmunity, and the subsequent discovery of immune checkpoint molecules. ${ }^{17}$ These molecules work as negative co-stimulatory signals to attenuate $\mathrm{T}$-cell responses to foreign antigens. ${ }^{18}$ Normal immune system response to nonself-antigen requires a step-wise process: a $T$ cell recognises and binds to an antigen presented by antigen presenting cells (APC; Signal 1), then a B7 ligand binds to a T-cell costimulatory molecule (Signal 2) to enhance T-cell activation and proliferation. ${ }^{19}$ If this process is interrupted, the immune system interprets the antigen as 'self', leading to tolerance. ${ }^{20}$ On the other hand, if Signal 2 is uncontrolled, it may 
lead to normal tissue damage and severe host injury. ${ }^{18}$ Checkpoint molecules allow the immune system to achieve homeostasis, but cancer cells can use this interaction to prevent an anticancer immune response. ${ }^{21}$

First identified in 1987, cytotoxic T-lymphocyteassociated protein-4 (CTLA-4) is a member of the Ig superfamily and homologous to the T-cell co-stimulatory protein CD28. It was the first molecule identified as a checkpoint co-inhibitory molecule. ${ }^{17}$ CTLA-4 becomes upregulated on the $T$ cell surface, ultimately binding B7 in competition with $\mathrm{CD} 28$, leading to suppression of $T$ cells and functioning as a co-inhibitory signal. ${ }^{22}$ Blocking the CTLA-4 receptor with therapeutic antibodies unleashes an immune response, as demonstrated in mouse model studies $^{23}$ (Figure 1). This discovery led to a radical shift in cancer immunotherapy, moving from the initial concept of activating the immune system to attack cancer cells via vaccination, to a strategy of removing the co-inhibitory signal that blocks $T$ cell responses.

In the early 2000s, scientists identified the programmed cell death-1 (PD-1) inhibitory receptor and its ligands (PD-L1 and PD-L2) as additional members of the co-inhibitory pathway maintaining T-cell tolerance and prevention of autoimmunity. ${ }^{24}$ PD-1 is expressed on $T$ cells, $B$ cells, natural killer cells, monocytes, and dendritic cells, but its functional and biochemical properties have been best studied in T cells. ${ }^{25}$

Upregulation of PD-1 ligands in the tumour microenvironment and their ligation to PD-1 on CD8+ $T$ cells is a key mechanism by which cancer cells limit the host immune response. ${ }^{26}$ PD- 1 is expressed on T cells after they have been activated. The PD-1/PD-L1 inhibitory mechanism leads to a selective suppression and exhaustion of tumourspecific $T$ cells. Thus, therapeutic targeting of the PD-1/PD-L1 inhibitory mechanism may impede T-cell exhaustion, and thus reinvigorate tumourspecific T cells to destroy the cancer ${ }^{27}$ (Figure 2).

\section{IMMUNE CHECKPOINT INHIBITORS IN BREAST CANCER: CURRENT CLINICAL EXPERIENCE}

Most immunotherapy clinical trials in breast cancer have focussed on CTLA-4 and PD-1/
PD-L1 inhibition. Two monoclonal antibodies that inhibit CTLA-4 have been studied in breast cancer: tremelimumab, a fully humanised IgG2 monoclonal antibody, and ipilimumab, a fully humanised monoclonal IgG1 antibody specific to human CTLA-4. Tremelimumab has no U.S. Food and Drug Administration (FDA)-approved indication. Ipilimumab is FDA-approved, both as monotherapy for melanoma and in combination with the anti-PD-1 inhibitor nivolumab for the treatment of melanoma, ${ }^{28}$ non-small cell lung cancer, ${ }^{29}$ renal cell cancer, and some colorectal cancers. There are five monoclonal antibodies targeting the PD-1/PD-L1 pathway with published clinical trials in breast cancer: the anti-PD-1 monoclonal antibodies pembrolizumab and nivolumab, and the anti-PD-L1 monoclonal antibodies atezolizumab, durvalumab, and avelumab. Table 1 highlights the completed and ongoing clinical trials discussed in this paper.

\section{CTLA-4 INHIBITORS IN BREAST CANCER}

\section{Tremelimumab}

In a small Phase I trial of tremelimumab in combination with exemestane, no objective responses were observed in a heavily pretreated ER+ MBC population. ${ }^{48}$ Stable disease after 12 weeks occurred in $42 \%$ of patients, with onethird having previously progressed on exemestane. The most frequent Grade 1 or 2 treatment-related adverse events (TRAE) were diarrhoea (46\%), pruritus (42\%), constipation (23\%), and fatigue (23\%). Five patients experienced Grade 3 TRAE. There were no Grade 4 TRAE. ${ }^{48}$ Only one serious $A E$ was observed, related to diarrhoea, pyrexia, and dehydration, not responding to oral steroids, and requiring hospitalisation. In a single-arm, open-label pilot study of tremelimumab and durvalumab, an overall response rate (ORR) of $17 \%$ was observed in 18 evaluable patients with treatment-resistant metastatic HER2-negative (-) breast cancer (O\% and 43\% ORR in the ER+ and TNBC cohorts, respectively). ${ }^{49}$ Hepatitis, rash, and electrolyte abnormalities were the most common TRAE. No Grade 4 or 5 TRAE were observed. Several additional clinical trials exploring combination systemic strategies with tremelimumab in breast cancer are ongoing..$^{52-54}$ 


\section{Lymph node}

Suppressed T cell

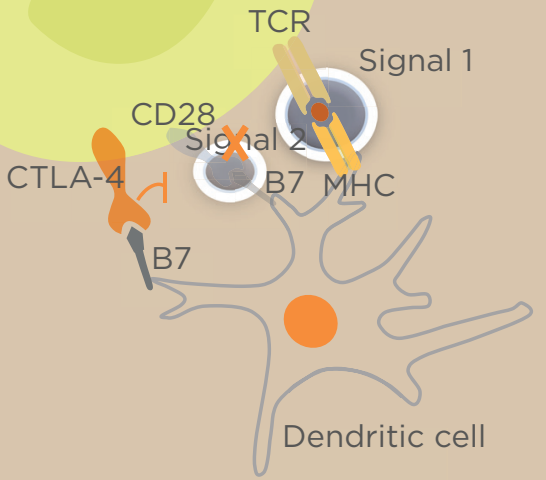

Activated T cell

CTLA-4 Anti-CTLA-4

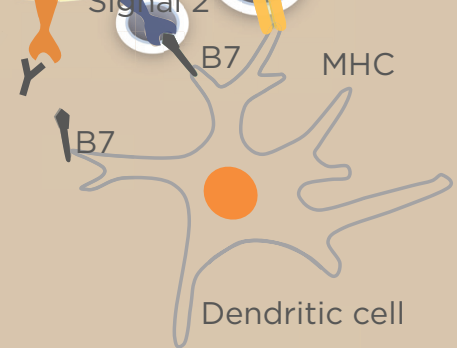

Figure 1: Binding of CTLA-4 to B7 costimulatory molecule blocks immunological Signal 2, impeding T-cell activation.

Using monoclonal antibodies to block CTLA-4 releases signal by CD28, enabling Signal 2 and T-cell activation. CD28: cluster of differentiation 28; CTLA-4: cytotoxic T-lymphocyte antigen-4; MHC: major histocompatibility complex; TCR: T-cell receptor.

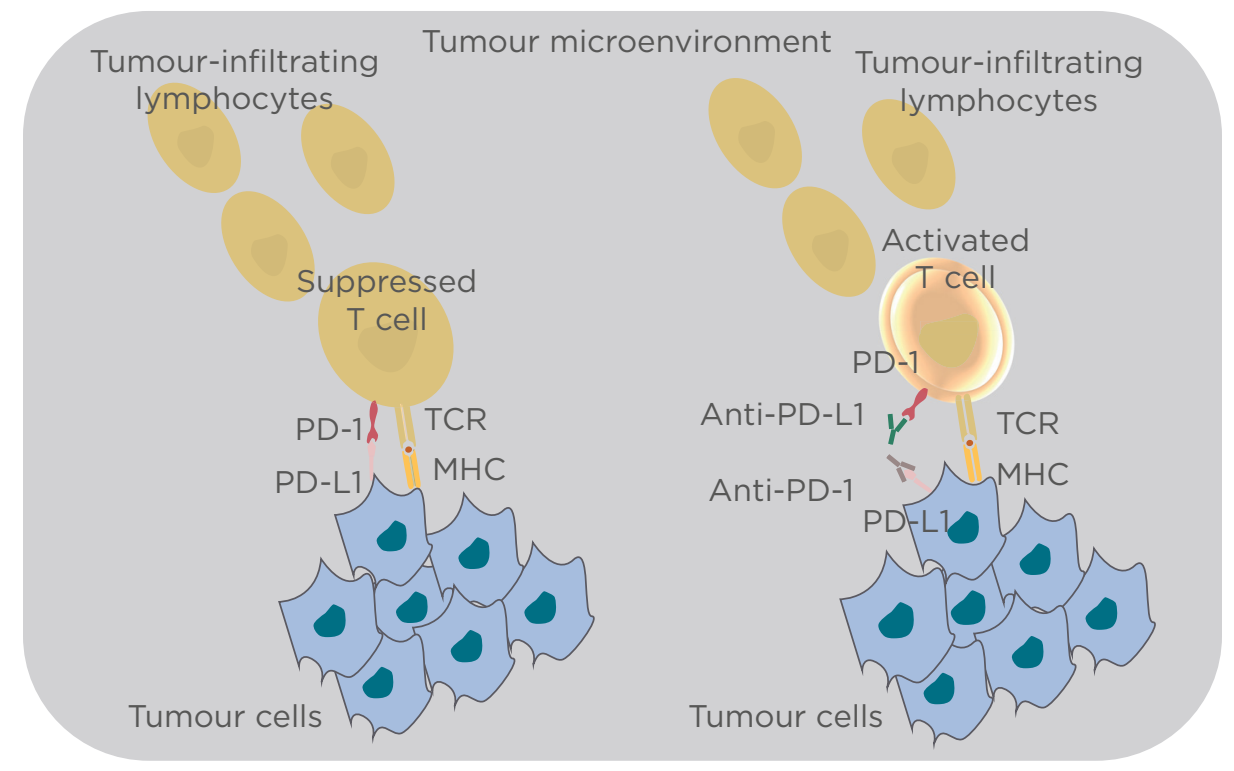

\section{Figure 2: Binding of PD-1 to PD-L1 suppresses the effect of the T-cell receptor.}

Using monoclonal antibodies to block PD-1 or PD-L1 releases the suppression, activating the T cell.

MHC: major histocompatibility complex; PD1: programmed cell death-1; PD-L1: programmed cell death ligand-1; TCR:

T-cell receptor. 
Table 1: Reported clinical trials with immune checkpoint inhibitors in metastatic or early breast cancer.

\begin{tabular}{|c|c|c|c|c|c|c|}
\hline Drug & Reference & Intervention & Phase & Population & $\begin{array}{l}\text { Number of } \\
\text { patients }\end{array}$ & Efficacy endpoints \\
\hline \multirow[t]{11}{*}{ Pembrolizumab } & Keynote-01230 & $\begin{array}{l}\text { Pembrolizumab } \\
\text { monotherapy }\end{array}$ & Ib & $\begin{array}{l}\text { mTNBC, PD-L1+, } \\
15.6 \% \text { first } \\
\text { line }\end{array}$ & 27 & $\begin{array}{l}\text { ORR: } 18.5 \% \\
\text { PFS: } 1.9 \text { months } \\
\text { OS: } 11.2 \text { months }\end{array}$ \\
\hline & Keynote-02831 & $\begin{array}{l}\text { Pembrolizumab } \\
\text { monotherapy }\end{array}$ & Ib & $\begin{array}{l}\mathrm{HR}+\mathrm{mBC}, \mathrm{PD}- \\
\mathrm{L} 1+\text {, prior } \\
\text { chemo/ } \\
\text { endocrine } \\
\text { therapy } \\
\text { allowed }\end{array}$ & 25 & $\begin{array}{l}\text { ORR: } 12.0 \% \\
\text { PFS: } 1.8 \text { months } \\
\text { OS: } 8.6 \text { months }\end{array}$ \\
\hline & $\begin{array}{l}\text { Keynote-086 } \\
\text { Cohort } A^{32}\end{array}$ & $\begin{array}{l}\text { Pembrolizumab } \\
\text { monotherapy }\end{array}$ & II & $\begin{array}{l}\text { mTNBC, PD- } \\
\text { L1+/-, second } \\
\text { line and beyond }\end{array}$ & 170 & $\begin{array}{l}\text { ORR: } 4.70 \% \\
\text { PFS: } 2.0 \text { months } \\
\text { OS: } 8.9 \text { months }\end{array}$ \\
\hline & $\begin{array}{l}\text { Keynote-086 } \\
\text { Cohort B }{ }^{33}\end{array}$ & $\begin{array}{l}\text { Pembrolizumab } \\
\text { monotherapy }\end{array}$ & 11 & $\begin{array}{l}\mathrm{mTNBC}, \mathrm{PD}-\mathrm{L} 1+, \\
\text { first line }\end{array}$ & 84 & $\begin{array}{l}\text { ORR: } 23.1 \% \\
\text { PFS: } 2.0 \text { months } \\
\text { OS: } 8.9 \text { months }\end{array}$ \\
\hline & ENHANCE $^{34}$ & $\begin{array}{l}\text { Pembrolizumab + } \\
\text { eribulin mesylate }\end{array}$ & $\mathrm{Ib} / \mathrm{II}$ & $\begin{array}{l}\text { mTNBC, PD-L1 } \\
+/-, \text { first to } \\
\text { third line }\end{array}$ & 107 & $\begin{array}{l}\text { ORR: } 26.4 \% \\
\text { PFS: } 4.2 \text { months } \\
\text { OS: } 17.7 \text { months }\end{array}$ \\
\hline & $J^{\prime} P C E^{35}$ & $\begin{array}{l}\text { Pembrolizumab + } \\
\text { abemaciclib }\end{array}$ & Ib & $\begin{array}{l}\mathrm{HR}+, \text { ERBB2- } \\
\mathrm{mBC} \text {, treatment } \\
\text { line } \mathrm{N} / \mathrm{A}\end{array}$ & 28 & $\begin{array}{l}\text { ORR: } 28.6 \% \\
\text { PFS: N/A } \\
\text { OS: N/A }\end{array}$ \\
\hline & TOPACIO ${ }^{36}$ & $\begin{array}{l}\text { Pembrolizumab + } \\
\text { niraparib }\end{array}$ & II & $\begin{array}{l}\text { mTNBC, first to } \\
\text { third line }\end{array}$ & 46 & $\begin{array}{l}\text { ORR: } 28.0 \% \\
\text { PFS: N/A } \\
\text { OS: N/A }\end{array}$ \\
\hline & PANACEA ${ }^{37}$ & $\begin{array}{l}\text { Pembrolizumab + } \\
\text { trastuzumab }\end{array}$ & $1 / I I$ & $\begin{array}{l}\text { HER2+ mBC, } \\
\text { second line and } \\
\text { beyond }\end{array}$ & 58 & $\begin{array}{l}\text { PD-L1+ } \\
\text { ORR: } 15.2 \% \\
\text { PFS: } 2.7 \text { months } \\
\text { OS: } 17.1 \text { months } \\
\end{array}$ \\
\hline & Keynote-17338 & $\begin{array}{l}\text { Cohort A: } \\
\text { Pembrolizumab } \\
+ \text { nab-paclitaxel } \\
\rightarrow \text { pembrolizumab } \\
+ \text { doxorubicin }+ \\
\text { cyclophosphamide } \\
\\
\text { Cohort B: } \\
\text { Pembrolizumab + nab- } \\
\text { paclitaxel + carboplatin } \\
\rightarrow \text { pembrolizumab } \\
+ \text { doxorubicin + } \\
\text { cyclophosphamide }\end{array}$ & Ib & $\begin{array}{l}\text { No prior therapy } \\
\text { LABC, TN }\end{array}$ & $\begin{array}{l}20 \text { (10 each } \\
\text { cohort) }\end{array}$ & $\begin{array}{l}\text { Cohort A: } \\
\text { ypTO ypNO: 50.0\% } \\
\text { ORR: 70.0\% } \\
\text { Cohort B: } \\
\text { ypTO ypNO: 80\% } \\
\text { ORR: } 90.0 \%\end{array}$ \\
\hline & I-SPY-2 39 & $\begin{array}{l}\text { Pembrolizumab } \\
+ \text { paclitaxel } \rightarrow \\
\text { doxorubicin }+ \\
\text { cyclophosphamide } \\
\text { versus control } \\
\text { (paclitaxel } \rightarrow \\
\text { doxorubicin }+ \\
\text { cyclophosphamide) }\end{array}$ & II & $\begin{array}{l}\text { No prior therapy } \\
\text { LABC HER2- } \\
\text { (includes TN } \\
\text { and ER+) }\end{array}$ & $\begin{array}{l}69 \\
\text { (pembrolizumab } \\
\text { arm) } \\
180 \text { (control } \\
\text { arm) }\end{array}$ & $\begin{array}{l}\text { Estimated pCR } \\
\text { (pembrolizumab versus } \\
\text { control): } \\
\text { TN: } 60.0 \% \text { versus } 20.0 \% \\
\text { ER+: } 34.0 \% \text { versus } 13.0 \%\end{array}$ \\
\hline & Keynote- $522^{40}$ & $\begin{array}{l}\text { Pembrolizumab or } \\
\text { placebo + paclitaxel } \\
\rightarrow \text { doxorubicin }+ \\
\text { cyclophosphamide }\end{array}$ & III & $\begin{array}{l}\text { Stage II and III } \\
\text { TNBC }\end{array}$ & 1,174 & $\begin{array}{l}\text { pembrolizumab versus } \\
\text { placebo: } \\
\text { pCR: } 64.8 \% \text { versus } 51.2 \% \\
\text { EFS: } 91.3 \% \text { versus } 85.3 \%\end{array}$ \\
\hline
\end{tabular}


Table 1 continued.

\begin{tabular}{|c|c|c|c|c|c|c|}
\hline Drug & Reference & Intervention & Phase & Population & $\begin{array}{l}\text { Number of } \\
\text { patients }\end{array}$ & Efficacy endpoints \\
\hline \multirow[t]{2}{*}{ Durvalumab } & MEDIOLA ${ }^{41}$ & Durvalumab + olaparib & II & $\begin{array}{l}B R C A 1 / 2- \\
\text { mutated, } \\
\text { ERBB2- } \\
\text { mBC, first line } \\
\text { and beyond }\end{array}$ & 25 & $\begin{array}{l}\text { ORR: } 52.0 \% \\
\text { PFS: N/A } \\
\text { OS: N/A }\end{array}$ \\
\hline & GeparNuevo ${ }^{42}$ & $\begin{array}{l}\text { 2-week induction with } \\
\text { durvalumab versus } \\
\text { placebo } \\
\text { Durvalumab + } \\
\text { nab-paclitaxel } \\
\rightarrow \text { durvalumab } \\
\text { + epirubicin + } \\
\text { cyclophosphamide } \\
\text { versus } \\
\text { placebo + nab- } \\
\text { paclitaxel } \rightarrow \text { placebo } \\
+ \text { epirubicin + } \\
\text { cyclophosphamide }\end{array}$ & II & $\begin{array}{l}\text { No prior therapy } \\
\text { LABC, TN }\end{array}$ & 174 & $\begin{array}{l}\text { pCR ypTO ypNO (durvalumab } \\
\text { versus placebo): } \\
\text { ITT: } 53.4 \% \text { versus } 44.2 \% \\
\text { induction: } 61.0 \% \text { versus } 41.4 \% \\
\text { age <40: } 69.2 \% \text { versus } 42.9 \%\end{array}$ \\
\hline Nivolumab & TONIC 43 & $\begin{array}{l}\text { Induction } \rightarrow \text { Nivolumab } \\
\text { versus no induction } \rightarrow \\
\text { nivolumab } \\
\text { Induction: radiation; } \\
\text { doxorubicin; } \\
\text { cyclophosphamide; } \\
\text { cisplatin }\end{array}$ & II & $\begin{array}{l}\text { mTNBC (<3 } \\
\text { lines of therapy) }\end{array}$ & 66 & $\begin{array}{l}\text { ORR: } \\
\text { no induction: } 17.0 \% \\
\text { radiation: } 8.0 \% \\
\text { doxorubicin: } 35.0 \% \\
\text { cyclophosphamide: } 8.0 \% \\
\text { cisplatin: } 23.0 \%\end{array}$ \\
\hline \multirow[t]{3}{*}{ Atezolizumab } & $\begin{array}{l}\text { Emens et al., }{ }^{44} \\
2018\end{array}$ & $\begin{array}{l}\text { Atezolizumab } \\
\text { monotherapy }\end{array}$ & la & $\begin{array}{l}\text { mTNBC, PD-L1+ } \\
\text { or -, first line } \\
\text { and beyond }\end{array}$ & 115 & $\begin{array}{l}\text { ORR PD-L1+: } 13.0 \% \\
\text { ORR PD-L1-: } 0.0 \% \\
\text { PFS: } 1.4 \text { months } \\
\text { OS: } 8.9 \text { months }\end{array}$ \\
\hline & $\begin{array}{l}\text { Adams et al., }{ }^{45} \\
2018\end{array}$ & $\begin{array}{l}\text { Atezolizumab + nab- } \\
\text { paclitaxel }\end{array}$ & $\mathrm{lb}$ & $\begin{array}{l}\text { mTNBC, PD-L1+ } \\
\text { or -, first to third } \\
\text { line }\end{array}$ & 33 & $\begin{array}{l}\text { ORR: } 39.0 \% \\
\text { PFS: } 5.5 \text { months } \\
\text { OS: } 14.7 \text { months }\end{array}$ \\
\hline & Impassion $130^{46}$ & $\begin{array}{l}\text { Atezolizumab + } \\
\text { nab-paclitaxel versus } \\
\text { placebo + nab- } \\
\text { paclitaxel }\end{array}$ & III & mTNBC first line & 900 & $\begin{array}{l}\text { PD-L1+ } \\
\text { PFS: } 7.5 \text { versus } 5.0 \text { months } \\
\text { OS: } 25.0 \text { versus } 15.5 \text { months }\end{array}$ \\
\hline Avelumab & JAVELIN ${ }^{47}$ & $\begin{array}{l}\text { Avelumab } \\
\text { monotherapy }\end{array}$ & Ib & $\begin{array}{l}\mathrm{mBC} \text { PD-L1+ } \\
\text { (TNBC, ER+/ } \\
\text { HER2-, HER2+) } \\
\end{array}$ & 168 & $\begin{array}{l}\text { ORR: } 3.0 \% \\
\text { PFS: } 5.9 \text { months } \\
\text { OS: } 8.1 \text { months }\end{array}$ \\
\hline \multirow[t]{3}{*}{ Tremelimumab } & $\begin{array}{l}\text { Vonderheide } \\
\text { et al.. }{ }^{48} 2010\end{array}$ & $\begin{array}{l}\text { Tremelimumab + } \\
\text { exemestane }\end{array}$ & I & $E R+m B C$ & 26 & $\begin{array}{l}\text { ORR: } 0.0 \% \\
\text { PFS: N/A } \\
\text { OS: N/A }\end{array}$ \\
\hline & $\begin{array}{l}\text { Santa-Maria et } \\
\text { al.., }{ }^{49} 2018\end{array}$ & $\begin{array}{l}\text { Tremelimumab + } \\
\text { durvalumab }\end{array}$ & Pilot & $\mathrm{ER}+$ or $\mathrm{TN} \mathrm{mBC}$ & 18 & $\begin{array}{l}\text { ORR: } 17.0 \% \\
\text { ORR TNBC: } 43.0 \%\end{array}$ \\
\hline & $\begin{array}{l}\text { McArthur et } \\
\text { al., }{ }^{50} 2017\end{array}$ & $\begin{array}{l}\text { Tremelimumab + } \\
\text { brain radiotherapy (+ } \\
\text { trastuzumab HER2+) }\end{array}$ & Pilot & $\begin{array}{l}\text { HER2+ or } \mathrm{TN} \\
\mathrm{mBC}\end{array}$ & 26 & $\begin{array}{l}\text { DCR outside brain: } \\
\text { HER2+: } 33.0 \% \\
\text { TNBC: } 10.0 \%\end{array}$ \\
\hline Ipilimumab & $\begin{array}{l}\text { McArthur et } \\
\text { al.,51 } 2016\end{array}$ & $\begin{array}{l}\text { Ipilimumab +/- } \\
\text { nivolumab + breast } \\
\text { cryoablation }\end{array}$ & Pilot & $\begin{array}{l}\text { HER2- } \\
\text { Nonmetastatic } \\
\text { BC }\end{array}$ & 24 & $\begin{array}{l}\text { No Grade } 3 / 4 \mathrm{AE} \\
\text { all patients had planned } \\
\text { surgery }\end{array}$ \\
\hline
\end{tabular}

AE: adverse events; BC: breast cancer; DCR: disease control rate; ER: oestrogen receptor; ERBB2: Erb-B2 receptor tyrosine kinase 2; HER2: human epidermal receptor 2; ITT: intention to treat; LABC: locally advanced breast cancer; mBC: metastatic breast cancer; mTNBC: metastatic triple-negative breast cancer; ORR: overall response rate; OS: overall survival; pCR: pathologic complete response; PD1: programmed cell death-1; PD-L1: programmed cell death ligand-1; PFS: progression-free survival; TN: triple negative; TNBC: triple-negative breast cancer. 
Local strategies, such as cryoablation and radiation, invoke inflammation and may improve antigen presentation by destroying tumour integrity.

Numerous preclinical studies have demonstrated that cryoablation and radiation synergise with $\mathrm{ICl}$ to prevent tumour rechallenge..$^{55}$ Consequently, there is considerable interest in clinical strategies that combine local therapies with $\mathrm{ICl}$. In one such study of tremelimumab with brain radiation for the treatment of breast cancer brain metastases, the disease control rate in the nonirradiated, noncentral nervous system metastases was $33 \%$ and $10 \%$ in the HER2+ and TNBC cohorts, respectively. ${ }^{50}$ An expansion of the study's HER2+ cohort is planned. A trial exploring $\mathrm{ICl}$ with hypofractioned radiation therapy for breast cancer and other tumours is underway. ${ }^{56} \mathrm{~A}$ further discussion of the role of cryoablation and immunotherapy in breast cancer is outlined below.

\section{Ipilimumab}

A pilot study to investigate the safety and feasibility of ipilimumab in combination with tumour cryoablation enrolled 19 patients with HER2- early-stage breast cancer, for whom mastectomy was planned, to receive cryoablation alone (Group A), single-dose ipilimumab at 10 $\mathrm{mg} / \mathrm{kg}$ (Group B), or both cryoablation and single-dose ipilimumab at $10 \mathrm{mg} / \mathrm{kg}$ (Group C). ${ }^{51}$ The results showed that cryoablation and ipilimumab was safe and well-tolerated, alone and in combination. Importantly, there was no surgery delay and no Grade 3 or 4 TRAE. ${ }^{51}$ The combination increased Th1-cytokine production, peripheral T-cell proliferation and activation, and intratumoural proliferation of effector $T$ cells relative to regulatory $T$ cells indicating both local and systemic antitumour immunity. ${ }^{57}$ After a median 66 months of follow-up, no recurrences have been reported as yet, and an expansion with five patients treated with ipilimumab and nivolumab demonstrated no new safety signal. ${ }^{58}$ This strategy is now being explored in a randomised Phase II study of cryoablation with ipilimumab and nivolumab versus standard of care in women with residual TNBC after standard-of-care chemotherapy for early-stage disease, a high-risk population with a $40 \%$ risk of recurrence. ${ }^{52}$ Other Phase II clinical trials are actively recruiting patients with breast cancer for treatment with ipilimumab in combination with other therapies. ${ }^{53,54}$
PD1/PD-L1 INHIBITORS IN BREAST CANCER

\section{Pembrolizumab}

Pembrolizumab is a highly selective humanised monoclonal antibody against PD-1 with clinical data in patients with TN, ER+, and HER2+ breast cancer. One of the first trials of pembrolizumab for breast cancer was the Keynote-012 trial, wherein patients with chemotherapy-resistant metastatic PD-L1+ TNBC were treated with single agent pembrolizumab. ${ }^{30}$ Safety was the primary endpoint with $56.3 \%$ of patients experiencing at least one TRAE, including $15.6 \%$ that were Grade 3-5. In the 27 patients who met the criteria for efficacy analysis, the ORR was $18.5 \% .^{30}$ In Cohort A of the Keynote-086 study, patients with chemotherapy-refractory metastatic TNBC were enrolled and pembrolizumab was associated with an ORR of $5.3 \%$ and $5.7 \%$ for the total cohort and PD-L1+ subset, respectively. ${ }^{32}$ In Cohort B of Keynote-086, 84 patients with PD-L1+ TNBC received single-agent pembrolizumab as firstline palliative therapy and an ORR of $21.4 \%$ was observed, indicating improved efficacy with administration earlier in the course of disease. ${ }^{33}$ In the Phase I/II ENHANCE-1 trial, pembrolizumab combined with eribulin mesylate conferred an ORR of $26.4 \%$ in patients who had received 0-2 prior lines of therapy for metastatic TNBC, regardless of PD-L1 status. ${ }^{34}$ In the Phase II TOPACIO trial, pembrolizumab was administered with niraparib, a PARP inhibitor, in 55 patients with metastatic TNBC, with a confirmed ORR of $21 \%$ reported. ${ }^{36}$

The Keynote-028 trial evaluated efficacy and safety of pembrolizumab monotherapy in patients with metastatic, PD-L1+, hormone therapy, and chemotherapy-resistant ER+ breast cancer, with an ORR of $12 \%$ reported. Among the 25 evaluable patients, 64\% experienced at least one TRAE and $16 \%$ experienced Grade 3 or $4 \mathrm{AE} .{ }^{56}$ Pembrolizumab has also been tested with the cyclin-dependent kinase 4/6 inhibitor abemaciclib in a Phase lb study with ER+, HER2-, previously treated metastatic breast cancer. ${ }^{49}$ For the 28 evaluable patients, the ORR was 14.3\%, with no concerning safety signals identified. The Phase Ib/II PANACEA trial demonstrated activity with pembrolizumab and trastuzumab in a trastuzumab-resistant HER2+ metastatic breast 
cancer population. ${ }^{37}$ In the second phase of this trial, a 15\% ORR and a $25 \%$ disease control rate were observed in the PD-L1+ participants.

In the curative-intent setting, combination strategies with pembrolizumab and chemotherapy have been tested in multiple trials. Early data from the I-SPY2 trial revealed that adding pembrolizumab to neoadjuvant paclitaxel prior to administration of neoadjuvant doxorubicin with cyclophosphamide resulted in an estimated pathologic complete response ( $p C R$ ) rate of $34 \%$ versus $13 \%$ in hormone receptor+, HER2- patients, and $60 \%$ versus $20 \%$ in TNBC patients. ${ }^{39}$ The Keynote 173 study is a multicentre six-arm Phase lb trial of pembrolizumab plus chemotherapy with TNBC patients suited to neoadjuvant therapy. ${ }^{38}$ Initial results comparing Arm A (without carboplatin) versus Arm B (with carboplatin) revealed $\mathrm{PCR}$ in breast and axilla of $50 \%$ and $80 \%$, respectively. ${ }^{38}$ In this small trial, all patients presented with TRAE, but all were nonfatal and few patients discontinued study treatment due to AE. The first Phase III data that confirmed the benefit of adding pembrolizumab to neoadjuvant chemotherapy in TNBC came from the Keynote 522 trial. ${ }^{40}$ This international multicentre trial randomised 1,174 patients in a 2:1 fashion to pembrolizumab plus chemotherapy versus placebo plus chemotherapy for 24 weeks, followed by surgery and adjuvant pembrolizumab or placebo for 27 weeks. Chemotherapy consisted of carboplatin plus neoadjuvant paclitaxel and doxorubicin plus cyclophosphamide. Primary endpoints were PCR and event-free survival. In the first interim analysis with a median 18-month follow-up, PCR rates were significantly increased in the pembrolizumab arm compared to placebo (64.8\% versus 51.2\%; $p=0.00055$ ). This benefit was independent of the PD-L1 status, although almost $80 \%$ of patients were PD-L1+. There was a strong favourable trend for an event-free survival benefit with the addition of pembrolizumab, but it has not yet met the predefined boundaries of statistical significance. ${ }^{40}$ Toxicity was mostly related to the chemotherapy backbone. The most common immune-mediated AE were infusion reactions (17.7\%) and hypothyroidism (14.9\%). One patient in the pembrolizumab arm died from pneumonitis. Several randomised Phase III clinical trials with pembrolizumab in different breast cancer subtypes and clinical settings are underway. ${ }^{59-63}$

\section{Nivolumab}

Nivolumab is an anti-PD-1 antibody with confirmed efficacy and safety in several tumour types, including melanoma, lung cancer, urothelial carcinoma, renal cell carcinoma, hepatocellular carcinoma, microsatellite instability-high colorectal cancer, head and neck cancer, and Hodgkin's lymphoma. ${ }^{64}$ In breast cancer, the TONIC trial investigated five strategies for induction therapy in metastatic TNBC including radiation therapy, doxorubicin, cyclophosphamide, cisplatin, or no induction treatment followed by nivolumab therapy. ${ }^{43}$ The ORR was highest in the doxorubicin group at $35 \%$, followed by $23 \%$ in the cisplatin arm, $17 \%$ in the no induction followed by nivolumab arm, and $8 \%$ in both the radiation and cyclophosphamide arms. In the nivolumab treatment phase, $20 \%$ of patients experienced Grade 3-5 TRAE. ${ }^{43}$ To further explore clinical activity of nivolumab in breast cancer, randomised Phase II clinical trials are ongoing. ${ }^{52-54}$

\section{Atezolizumab}

Atezolizumab is a humanised IgG1 monoclonal antibody that targets PD-L1. In a Phase la trial, atezolizumab was studied in 115 patients with metastatic TNBC. The unconfirmed ORR was 13\% in PD-L1+ tumours and 5\% in PD-L1- tumours. ${ }^{44}$ Combination therapy with atezolizumab and chemotherapy was first tested in a Phase $1 \mathrm{~b}$ trial that enrolled patients with metastatic TNBC, regardless of the PD-L1 status. ${ }^{45}$ Although safety was the primary endpoint, the ORR was 39.5\%. Responses occurred in patients with both PDL1+ and PD-L1- disease and were higher in first versus later-line settings with an ORR of $53.8 \%$ and 30.0\%, respectively. Grade 3-4 haematologic toxicity occurred in more than half of the patients, but this was manageable. ${ }^{45}$ Based on these findings, a Phase III randomised clinical trial was designed and recently published. ${ }^{46}$ Over 900 patients with previously untreated metastatic TNBC were randomised to neoadjuvant paclitaxel/ atezolizumab or neoadjuvant paclitaxel/placebo. With co-primary endpoints of progression-free survival and overall survival (OS) in the overall and PD-L1+ population, this trial gave overall positive results. There was a significant increase in progression-free survival in the overall and the PDL1+ population. Although the OS benefit was not statistically significant in the overall population, 
there was a clinically significant increase in the median OS with the addition of atezolizumab in the PD-L1+ population (25.0 versus 15.5 months). ${ }^{46}$ The combination of atezolizumab plus neoadjuvant paclitaxel was recently approved in several countries for use in patients with metastatic TNBC. As a result, several randomised Phase III trials are being conducted in patients with breast cancer either in the metastatic setting or in the curative-intent scenario. ${ }^{65-69}$

\section{Durvalumab}

Durvalumab is another human monoclonal antibody that inhibits interaction between PD-1 and PD-L1. The drug has demonstrated safety and clinical activity in other tumour types, such as urothelial carcinoma, head and neck cancer, and non-small cell lung cancer.70-72 In the placebo-controlled GeparNuevo study, 174 patients with early-stage TNBC were randomised to standard neoadjuvant anthracycline/taxane chemotherapy with or without durvalumab. ${ }^{42}$ In the window-phase, 117 patients received durvalumab or placebo 2 weeks prior to the start of chemotherapy. Treatment with durvalumab resulted in a higher $\mathrm{pCR}$ rate, $53.4 \%$ versus $44.2 \%$, but this result did not reach the predefined statistical endpoint. In the predefined subgroup analysis, patients receiving durvalumab in the window-phase had significantly higher $\mathrm{pCR}$ rates compared to placebo (61.0\% versus $41.4 \%$; $\mathrm{p}=0.052$ ). The most common immune-related $A E$ were thyroid dysfunction of any grade, which was experienced in $47.0 \%$ of patients. ${ }^{42}$ In the Phase II MEDIOLA trial, durvalumab was combined with olaparib, another PARP inhibitor, in 25 patients with BRCA1/2-mutated, HER2- metastatic breast cancer with a confirmed ORR of $52 \%$ reported. ${ }^{41}$ To further explore this drug efficacy and safety, several Phase II and III randomised clinical trials in breast cancer are open to accrual. ${ }^{73-77}$

\section{Avelumab}

Avelumab is another monoclonal antibody directed against PD-L1 with clinical activity and safety tested in several tumour types. ${ }^{78-79}$ JAVELIN Solid Tumour is an international, openlabel, Phase I trial in patients with advanced solid malignancies being treated with avelumab. The Phase Ib breast cancer cohort included 168 previously treated patients. ${ }^{47}$ The ORR was 3.0\% in the overall patient population. The ORR in the TNBC, HER2+, and hormone+ subtypes were 5.2\%, $3.8 \%$, and $2.8 \%$, respectively. ${ }^{47}$ TRAE occurred in $68.0 \%$ of the patients with $13.7 \%$ experiencing Grade 3 or higher. ${ }^{47}$ Although limited clinical data are available with avelumab in breast cancer, several randomised clinical trials are under way in different clinical settings. ${ }^{80-84}$

\section{CONCLUSION}

Immunotherapy in breast cancer has proven its potential over years of treatments. From the preclinical rationale to registration Phase III trials, a great deal has been learnt about the efficacy and mechanisms of action. Specifically, $\mathrm{ICl}$ alone is safe, but has limited efficacy in the metastatic setting across subtypes based on early-phase trials. ${ }^{32,44,79}$ Strategies that increase antigen release and potentiate the $\mathrm{ICl}$ therapeutic index are being explored in numerous trials combining anti-PD-1/ L1 with chemotherapy, targeted therapies, or locoregional therapies with the goal of increasing response rates and duration of response. ${ }^{34,45}$ In metastatic TNBC, first-line treatment with the antiPD-L1 inhibitor atezolizumab and neoadjuvant paclitaxel chemotherapy is now the standard of care for patients with PD-L1+ tumours. ${ }^{46}$ Small Phase II trials of combination chemotherapy and anti-PD-1 monoclonal antibodies demonstrated a significant increase in $\mathrm{PCR}$ rates, but with added toxicity. ${ }^{38,39,42}$ Several randomised Phase III trials are under way, either in the curative intent or in the metastatic setting and exploring the combination of $\mathrm{ICl}$ and chemotherapy in treating $\mathrm{ER}+, \mathrm{HER} 2+$, or TNBC. The future of immunotherapy, in particular $\mathrm{ICl}$, for the treatment of breast cancer is very promising, and it is hoped that rationale $\mathrm{ICl}$ combination strategies will ultimately improve cure rates and advance the treatment landscape. 


\section{References}

1. Hammond ME et al. American Society of Clinical Oncology/ College of American Pathologists guideline recommendations for immunohistochemical testing of estrogen and progesterone receptors in breast cancer. J Clin Oncol. 2010;28(16):2784-95.

2. Wolff $\mathrm{AC}$ et al. American Society of Clinical Oncology College of American Pathologists recommendations for human epidermal growth factor receptor 2 testing in breast cancer: American Society of Clinical Oncology/College of American Pathologists clinical practice guideline update. J Clin Oncol. 2013;31(31):3997-4013.

3. Cancer Genome Atlas Network. Comprehensive molecular portraits of human breast tumours. Nature. 2012;490(7418):61-70.

4. Harbeck N, Gnant M. Breast cancer. Lancet. 2017;389(10074):1134-50.

5. Cortazar P et al. Pathological complete response and long-term clinical benefit in breast cancer: the CTNeoBC pooled analysis. Lancet. 2014;384(9938):164-72

6. Nagini S. Breast Cancer: current molecular therapeutic targets and new players. Anticancer Agents Med Chem. 2017;17(2):152-63.

7. Swain SM et al. CLEOPATRA Study Group. Pertuzumab, trastuzumab, and docetaxel in HER2-positive metastatic breast cancer. N Engl J Med. 2015;372(8):724-34

8. Diéras $V$ et al. Trastuzumab emtansine versus capecitabine plus lapatinib in patients with previously treated HER2-positive advanced breast cancer (EMILIA): a descriptive analysis of final overall survival results from a randomised, open-label, Phase 3 trial. Lancet Oncol. 2017;18(6):732 42.

9. Robson $\mathrm{M}$ et al. Olaparib for metastatic breast cancer in patients with a germline BRCA mutation. $\mathrm{N}$ Engl J Med. 2017;377(6):523-33.

10. Gobbini E et al. Time trends of overall survival among metastatic breast cancer patients in the real-life ESME cohort. Eur J Cancer. 2018;96:17-24.

11. Underwood JC. Lymphoreticular infiltration in human tumors: prognostic and biological implications: a review. $\mathrm{Br} \mathrm{J}$ Cancer $1974 ; 30(6): 538-48$.

12. Loi $\mathrm{S}$ et al. Tumor infiltrating lymphocytes are prognostic in triple negative breast cancer and predictive for trastuzumab benefit in early breast cancer: results from the FinHER trial. Ann Oncol. 2014;25(8):1544-50.

13. Stanton SE et al. Variation in the incidence and magnitude of tumor- infiltrating lymphocytes in breast cancer subtypes: a systematic review. JAMA Oncol. 2016;2(10):1354-60

14. Wimberly $\mathrm{H}$ et al. PD-L1 expression correlates with tumor-infiltrating lymphocytes and response to neoadjuvant chemotherapy in breast cancer. Cancer Immunol Res. 2015;3(4):326-32.

15. Coley WB. The treatment of malignant tumors by repeated inoculations of erysipelas: with a report of ten original cases. 1893. Clin Orthop Relat Res. 1991;(262):3-11.

16. Bodey B et al. Failure of cancer vaccines: the significant limitations of this approach to immunotherapy. Anticancer Res. 2000;20(4):2665-76.

17. Brunet JF et al. A new member of the immunoglobulin superfamily-CTLA-4. Nature. 1987;328(6127):26770

18. Tivol EA et al. Loss of CTLA-4 leads to massive lymphoproliferation and fatal multiorgan tissue destruction, revealing a critical negative regulatory role of CTLA-4. Immunity. 1995;3(5):541-7.

19. Bretscher PA. A two-step, two-signal model for the primary activation of precursor helper T cells. Proc Natl Acad Sci U S A. 1999;96(1):185-90.

20. Cogdill AP et al. Hallmarks of response to immune checkpoint blockade. Br J Cancer. 2017;117(1):1-7.

21. Page DB et al. Tumor immunology and cancer immunotherapy: summary of the 2014 SITC primer. J Immunother Cancer. 2015:3:25.

22. Waterhouse $\mathrm{P}$ et al. Lymphoproliferative disorders with early lethality in mice deficient in Ctla-4. Science. 1995;270(5238):9858.

23. Allison JP et al. Manipulation of costimulatory signals to enhance antitumor T-cell responses. Curr Opin Immunol. 1995;7(5):682-6.

24. Freeman GJ et al. Engagement of the PD-1 immunoinhibitory receptor by a novel B7 family member leads to negative regulation of Iymphocyte activation. J Exp Med. 2000;192(7):1027-34.

25. Ishida $Y$ et al. Induced expression of PD-1, a novel member of the immunoglobulin gene superfamily, upon programmed cell death. EMBO J. 1992;11(11):3887-95.

26. Ahmadzadeh $M$ et al. Tumor antigenspecific CD8 T cells infiltrating the tumor express high levels of PD-1 and are functionally impaired. Blood. 2009;114(8):1537-44.

27. Topalian SL et al. Targeting the PD-1/ B7-H1(PD-L1) pathway to activate anti-tumor immunity. Curr Opin Immunol. 2012;24(2):207-12.
28. Larkin $\mathrm{J}$ et al. Combined nivolumab and ipilimumab or monotherapy in untreated melanoma. N Engl J Med. 2015;373(1):23-34.

29. Hellmann MD et al. Nivolumab plus ipilimumab in lung cancer with a high tumor mutational burden. N Engl J Med. 2018;378(22):2093-104.

30. Nanda R et al. Pembrolizumab in patients with advanced triplenegative breast cancer: Phase Ib KEYNOTE-012 study. J Clin Oncol. 2016;34(21):2460-7.

31. Rugo HS et al. Safety and antitumor activity of pembrolizumab in patients with estrogen receptor-positive/ human epidermal growth factor receptor 2-negative advanced breast cancer. Clin Cancer Res. 2018;24(12):2804-11.

32. Adams $\mathrm{S}$ et al. Pembrolizumab monotherapy for previously treated metastatic triple-negative breast cancer: cohort A of the Phase II KEYNOTE-086 study. Ann Oncol. 2019;30(3):397-404

33. Adams $S$ et al. Pembrolizumab monotherapy for previously untreated, PD-L1-positive, metastatic triple-negative breast cancer: cohort $B$ of the Phase II KEYNOTE-086 study. Ann Oncol. 2019;30(3):405-11.

34. Tolaney SM et al. Phase $1 \mathrm{~b} / 2$ study to evaluate eribulin mesylate in combination with pembrolizumab in patients with metastatic triplenegative breast cancer. Abstract PD6-13. San Antonio Breast Cancer Symposium, 5-9 December, 2017.

35. Tolaney SM et al. Updated efficacy, safety, \& PD-L1 status of patients with HR+, HER2- metastatic breast cancer administered abemaciclib plus pembrolizumab. J Clin Oncol. 2018;36(Suppl 15):1059.

36. Vinayak $S$ et al. Open-label clinical trial of niraparib combined with pembrolizumab for treatment of advanced or metastatic triplenegative breast cancer. JAMA Oncol. 2019;5(8):1132-40. [Epub ahead of print].

37. Loi S et al. Pembrolizumab plus trastuzumab in trastuzumab-resistant, advanced, HER2-positive breast cancer (PANACEA): a single-arm, multicentre, Phase 1b-2 trial. Lancet Oncol. 2019;20(3):371-82.

38. Schmid P et al. Pembrolizumab (pembro) + chemotherapy (chemo) as neoadjuvant treatment for triple negative breast cancer (TNBC): preliminary results from KEYNOTE-173. J Clin Oncol. 2017;35(Suppl 15):556.

39. Nanda R et al. Pembrolizumab plus standard neoadjuvant therapy for high-risk breast cancer (BC): results from I-SPY 2. J Clin Oncol. 2017;35(Suppl 15):506. 
40. Schmid $P$ et al. KEYNOTE-522 Phase 3 study of pembrolizumab + chemotherapy versus placebo + chemotherapy as neoadjuvant treatment, followed by pembrolizumab versus placebo as adjuvant treatment for early triplenegative breast cancer (TNBC). Ann Oncol. 2019;30(Suppl 5):v851-v934.

41. Domchek $\mathrm{S}$ et al. An open-label, multitumor, Phase II basket study of olaparib and durvalumab (MEDIOLA) results in germline $B R C A$-mutated (gBRCAm) HER2-negative metastatic breast cancer (MBC). Abstract PD6-11. San Antonio Breast Cancer Symposium, 5-9 December, 2017.

42. Loibl S et al. A randomised Phase II study investigating durvalumab in addition to an anthracycline taxanebased neoadjuvant therapy in early triple negative breast cancer - clinical results and biomarker analysis of GeparNuevo study. Ann Oncol. 2019;30(8):1279-88.

43. Voorwerk $L$ et al. Immune induction strategies in metastatic triplenegative breast cancer to enhance the sensitivity to PD-1 blockade: the TONIC trial. Nat Med. 2019;25(6):9208.

44. Emens LA et al. Long-term clinical outcomes and biomarker analyses of atezolizumab therapy for patients with metastatic triple-negative breast cancer: a Phase 1 study. JAMA Oncol. 2018;5(1):74-82.

45. Adams S et al. Atezolizumab plus nab-paclitaxel in the treatment of metastatic triple-negative breast cancer with 2-year survival follow-up: a Phase 1b clinical trial. JAMA Oncol. 2018;5(3):334-42.

46. Schmid $P$ et al. IMpassion130 Tria Investigators. Atezolizumab and nab-paclitaxel in advanced triplenegative breast cancer. N Engl J Med. 2018;379(22):2108-21.

47. Dirix LY et al. Avelumab, an antiPD-L1 antibody, in patients with locally advanced or metastatic breast cancer: a Phase 1b JAVELIN solid tumor study. Breast Cancer Res Treat. 2018;167(3):671-86.

48. Vonderheide $\mathrm{RH}$ et al. Tremelimumab in combination with exemestane in patients with advanced breast cancer and treatment-associated modulation of inducible costimulator expression on patient $T$ cells. Clin Cancer Res. 2010:16(13):3485-94.

49. Santa-Maria CA et al. A pilot study of durvalumab and tremelimumab and immunogenomic dynamics in metastatic breast cancer. Oncotarget. 2018;9(27):18985-96.

50. McArthur $\mathrm{H}$ et al. CTLA4 blockade with HER2-directed therapy $(\mathrm{H})$ yields clinical benefit in women undergoing radiation therapy (RT) for HER2-positive (HER2+) breast cancer brain metastases (BCBM). Abstract 4705. AACR Annual Meeting, 1-5
51. McArthur $\mathrm{HL}$ et al. A pilot study of preoperative single-dose Ipilimumab and/or cryoablation in women with early-stage breast cancer with comprehensive immune profiling. Clin Cancer Res. 2016;22(23):5729-37.

52. Cedars-Sinai Medical Center. Perioperative ipilimumab+nivolumab and cryoablation versus standard care in women with triple-negative breast cancer. NCT03546686. https://clinicaltrials.gov/ct2/show/ NCT03546686

53. Centre Leon Berard. Evaluate the clinical benefit of a post-operative treatment associating radiotherapy + nivolumab + ipilimumab versus radiotherapy + capecitabine for triple negative breast cancer patients with residual disease (Breastlmmune03). NCT03818685. https://clinicaltrials. gov/ct2/show/NCT03818685.

54. Oslo University Hospital. Phase Ilb study evaluating immunogenic chemotherapy combined with ipilimumab and nivolumab in breast cancer (ICON). NCTO3409198. https://clinicaltrials.gov/ct2/show/ NCT03409198.

55. Waitz $\mathrm{R}$ et al. Potent induction of tumor immunity by combining tumor cryoablation with anti-CTLA-4 therapy. Cancer Res. 2012;72(2):4309.

56. Abramson Cancer Center of the University of Pennsylvania. Trial of hypofractionated radiotherapy in combination with MEDI4736 and tremelimumab for patients with metastatic melanoma and lung, breast and pancreatic cancers. NCTO2639026. https://clinicaltrials. gov/ct2/show/NCTO2639026.

57. Page DB et al. Pre-operative immunotherapy with tumor cryoablation (cryo) plus ipilimumab (ipi) induces potentially favorable systemic and intratumoral immune effects in early stage breast cancer (ESBC) patients. J Immunother Cancer. 2015;3(Suppl 1):06.

58. Comen EA et al. Preoperative checkpoint inhibition (CPI) and cryoablation (Cryo) in women with early-stage breast cancer (ESBC). J Clin Oncol. 2019;37(Suppl 15):592.

59. Merck Sharp \& Dohme Corp. Study of pembrolizumab (MK-3475) versus placebo in combination with neoadjuvant chemotherapy \& adjuvant endocrine therapy in the treatment of early-stage estrogen receptor-positive, human epiderma growth factor receptor 2-negative (ER+/HER2-) breast cancer (MK-3475-756/KEYNOTE-756). NCTO3725059. https://clinicaltrials. gov/ct2/show/NCT03725059.

60. Merck Sharp \& Dohme Corp. Study of pembrolizumab (MK-3475) plus chemotherapy vs placebo plus chemotherapy as neoadjuvant therapy and pembrolizumab vs placebo as adjuvant therapy in participants with triple negative breast cancer (TNBC) (MK-3475522/KEYNOTE-522). NCTO3036488. https://clinicaltrials.gov/ct2/show/ NCT03036488.

61. Merck Sharp \& Dohme Corp. Study of pembrolizumab (MK-3475) plus chemotherapy vs. placebo plus chemotherapy for previously untreated locally recurrent inoperable or metastatic triple negative breast cancer (MK-3475355/KEYNOTE-355). NCTO2819518. https://clinicaltrials.gov/ct2/show/ NCT02819518.

62. National Cancer Institute $(\mathrm{NCl})$ Pembrolizumab in treating patients with triple-negative breast cancer. NCTO2954874. https://clinicaltrials. gov/ct2/show/NCTO2954874.

63. National Cancer Institute ( $\mathrm{NCl}$ ). Paclitaxel, trastuzumab, and pertuzumab with or without atezolizumab in treating patients with metastatic breast cancer. NCT03199885. https://clinicaltrials. gov/ct2/show/NCT03199885.

64. Ribas A, Wolchok JD. Cancer immunotherapy using checkpoint blockade. Science. 2018;359 (6382):1350-55.

65. Hoffmann-La Roche. A study comparing atezolizumab (anti PDL1 antibody) in combination with adjuvant anthracycline/taxane-based chemotherapy versus chemotherapy alone in patients with operable triple-negative breast cancer (IMpassion030). NCT03498716. https://clinicaltrials.gov/ct2/show/ NCT03498716.

66. Hoffmann-La Roche. A study to investigate atezolizumab and chemotherapy compared with placebo and chemotherapy in the neoadjuvant setting in participants with early stage triple negative breast cancer (IMpassion 031). NCT03197935. https://clinicaltrials.gov/ct2/show/ NCT03197935.

67. Hoffmann-La Roche. A study of atezolizumab and paclitaxel versus placebo and paclitaxel in participants with previously untreated locally advanced or metastatic triple negative breast cancer (TNBC) (IMpassion131). NCTO3125902. https://clinicaltrials.gov/ct2/show/ NCT03125902.

68. Hoffmann-La Roche. A study of the efficacy and safety of atezolizumab plus chemotherapy for patients with early relapsing recurrent triple-negative breast cancer (IMpassion132). NCT03371017. https://clinicaltrials.gov/ct2/show/ NCT03371017.

69. Fondazione Michelangelo. Neoadjuvant therapy in triple negative breast cancer with antiPDL1 (NeoTRIPaPDL1). NCTO2620280. 
https://clinicaltrials.gov/ct2/show/ NCTO2620280.

70. Powles T et al. Efficacy and safety of durvalumab in locally advanced or metastatic urothelial carcinoma: updated results from a Phase 1/2 open-label study. JAMA Oncol. 2017;3(9):e172411.

71. Segal $\mathrm{NH}$ et al. Updated safety and efficacy of durvalumab (MEDI4736), an anti-PD-L 1 antibody, in patients from a squamous cell carcinoma of the head and neck ( $\mathrm{SCCHN}$ ) expansion cohort. Abstract 9490. European Society for Medical Oncology Congress, 7-11 October, 2016.

72. Garassino $M C$ et al. Durvalumab as third-line or later treatment for advanced non-small-cell lung cancer (ATLANTIC): an open-label, singlearm, Phase 2 study. Lancet Oncol. 2018;19(4):521-36.

73. King Faisal Specialist Hospital \& Research Center. study of safety and efficacy of durvalumab in combination with paclitaxel in metastatic triple negative breast cancer patients. NCTO2628132. https://clinicaltrials.gov/ct2/show/ NCTO2628132.

74. Chang J. Durvalumab with trastuzumab and pertuzumab in HER2-enriched breast cancer (DTP).
NCT03820141. https://clinicaltrials. gov/ct2/show/NCT03820141.

75. Cedars-Sinai Medical Center. Pre-operative non-anthracycline chemotherapy, durvalumab +/- radiation therapy in triple negative breast cancer (PANDORA). NCT03872505. https://clinicaltrials.gov/ct2/show/ NCT03872505?term=NCT03872505.

76. Duke University. Phase II multicenter study of durvalumab and olaparib in platinum treated advanced triple negative breast cancer (DORA) (DORA). NCT03167619. https://clinicaltrials.gov/ct2/show/ NCT03167619.

77. Grand Hôpital de Charleroi. Safety and efficacy of durvalumab combined to neoadjuvant chemotherapy in localized luminal B HER2(-) and triple negative breast cancer (B-IMMUNE). NCT03356860. https://clinicaltrials. gov/ct2/show/NCT03356860.

78. Kaufman $\mathrm{HL}$ et al. Avelumab in patients with chemotherapyrefractory metastatic Merkel cell carcinoma: a multicentre, singlegroup, open-label, Phase 2 trial. Lancet Oncol. 2016;17(10):1374-85.

79. Apolo $A B$ et al. Avelumab, an antiprogrammed death-ligand 1 antibody, in patients with refractory metastatic urothelial carcinoma: results from a multicenter, Phase lb study. J Clin Oncol. 2017;35(19):2117-24.

80. Georgetown University. TALAVE: Induction talazoparib followed by combination of talazoparib and avelumab in advanced breast cancer. NCT03964532. https://clinicaltrials. gov/ct2/show/NCT03964532.

81. Krop IE. The AVIATOR Study: trastuzumab and vinorelbine with avelumab or avelumab \& utomilumab in advanced HER2+ breast cancer. NCT03414658. https://clinicaltrials gov/ct2/show/NCT03414658.

82. Sidney Kimmel Comprehensive Cancer Center at Johns Hopkins. neoadjuvant tamoxifen, palbociclib, avelumab in estrogen receptor positive breast cancer (ImmunoADAPT). NCTO3573648. https://clinicaltrials.gov/ct2/show/ NCTO3573648.

83. Istituto Oncologico Veneto IRCCS Adjuvant treatment for highrisk triple negative breast cancer patients with the anti-PD-I1 antibody avelumab (A-Brave). NCTO2926196. https://clinicaltrials.gov/ct2/show/ NCTO2926196.

84. Dana-Farber Cancer Institute. Palbociclib after CDK and endocrine therapy (PACE). NCTO3147287. https://clinicaltrials.gov/ct2/show/ NCT03147287. 